\title{
Optimization of the Parameters Influencing the Photo-Fenton Process for the Decolorization of Reactive Red 198 (RR198)
}

\author{
Mansooreh Dehghani ${ }^{1}$; Mohammad Mehdi Taghizadeh ${ }^{2}$; Talat Gholami ${ }^{1}$; Mahshid Ghadami ${ }^{1}$; \\ Laila Keshtgar ${ }^{2}$; Zahra Elhameyan ${ }^{1}$; Mohammad Reza Javaheri ${ }^{1}$; Narges Shamsedini ${ }^{1, *}$; \\ Fatemeh Jamshidi ${ }^{1}$; Samaneh Shahsavani ${ }^{1}$; Masoud Ghanbarian ${ }^{1}$ \\ ${ }^{1}$ Department of Environmental Health Engineering, School of Health, Student Research Committee, Shiraz University of Medical Sciences, Shiraz, IR Iran \\ ${ }^{2}$ Islamic Azad University, Estahban Branch, Estahban, IR Iran \\ ${ }^{*}$ Corresponding author: Narges Shamsedini, Department of Environmental Health Engineering, School of Health, Student Research Committee, Shiraz University of Medical \\ Sciences, Shiraz, IR Iran. Tel: +98-9164490350, Fax:+98-7137260225, E-mail: nshamsedin@sums.ac.ir
}

Received: February 27, 2015; Revised: March 10, 2015; Accepted: March 26, 2015

\begin{abstract}
Background: Reactive dyes, anionic compounds with high water solubility, are widely used in textile industries.
Objectives: The present study aimed to assess the feasibility of the photo-Fenton process in removing Reactive Red 198 dye from aqueous solutions and determine the optimal conditions for maximum removal.

Materials and Methods: This study was performed on a laboratory scale using a 4-liter photochemical reactor. The spectrophotometer DR5000 (wavelength $520 \mathrm{~nm}$ ) was used to determine the dye concentration. The effect of the influencing parameters, including pH (3-9), $\mathrm{Fe}$ (II) concentration (10-200 mg/L), $\mathrm{H}_{2} \mathrm{O}_{2}$ concentration (25-150 mg/L), initial dye concentration (50-200 mg/L), and reaction time (15-120 minutes) were studied.

Results: According to the results, the photo-Fenton $\left(\mathrm{UV} / \mathrm{H}_{2} \mathrm{O}_{2} / \mathrm{Fe}(\mathrm{II})\right)$ process significantly removed dye from the aqueous solution. The Reactive Red 198 dye removal efficiency from aqueous solutions was more than $99 \%$ at optimal conditions $\left(\mathrm{pH}=3\right.$, $\mathrm{Fe}(\mathrm{II})=10 \mathrm{mg} / \mathrm{L}, \mathrm{H}_{2} \mathrm{O}_{2}=$ $75 \mathrm{mg} / \mathrm{L}$, initial dye concentration $=50 \mathrm{mg} / \mathrm{L}$, and reaction time $=120$ minutes $)$.

Conclusions: The present study demonstrated that the $\mathrm{UV} / \mathrm{H}_{2} \mathrm{O}_{2} / \mathrm{Fe}$ (II) process could be used as an efficient, reliable method for removing Reactive Red 198 dye from textile wastewater.
\end{abstract}

Keywords: Reactive Red 198; Wastewater; Decolorization; Dye Removal

\section{Background}

The consumption of water is quite high during the dying process in textile and finishing industries. The highly toxic wastewater is discharged in large quantities with different characteristics into the receiving water and, thus, threatens their quality $(1,2)$. In addition, the organic compounds in most of the highly consumed dyes have a very low biodegradability and persist in the aquatic environment (3-5). Most textile wastewater contains high chemical oxygen demand (COD), and the hydrolysis of organic compounds may happen in alkaline media prior to any treatment process (4). Moreover, the cost of treatment is considerable for this type of wastewater.

Dyes are aromatic compounds which absorb the visible light at 350 to $700 \mathrm{~nm}(6,7)$. They are categorized into 20 to 30 groups based on their chemical structures (2). Dyes are used in many different industries such as textile, wood, pulp and paper, tannery, cosmetic, nutrition, and electroplating (8-10). Nearly $15 \%$ of the annual consumption of dyes in textile industries enters wastewater during dyeing processing $(11,12)$. Since dye compounds usually contain benzene ring, the discharge of untreated wastewater decreases the quality of the receiving water (13). In general, dyes used in textile industries are divided into several groups, including anionic dyes (acidic, direct, and reactive), cationic dyes (alkaline dyes), and non-anionic dyes (disperse dyes) (14). Reactive dyes are easily dissolved in water and used in many dying processes. They are specially used for dying wool and polyamide fiber (2). This group of dyes is widely used in the textile industry because of their variety, easy applicability, desired stability of the finished product, and low energy consumption (13). Reactive Red 198 dye $\left(\mathrm{C}_{27} \mathrm{H}_{18} \mathrm{ClN}_{7} \mathrm{Na}_{4} \mathrm{O}_{15} \mathrm{~S}_{5}\right)$ is mostly utilized in the textile industry with the maximum absorption at $530 \mathrm{~nm}$. Due to the high rate of hydrolysis in alkaline condition, large portions of reactive dyes (30\%) are wasted during dyeing processes and discharged in wastewater streams (1).

The conventional chemical processes (such as coagulation and flocculation, membrane technology, electrochemical system, precipitation, ozonation, ultrasound wave, chemical oxidation, and adsorption) are generally used to remove dyes from textile wastewater $(13,14)$. Ba-

Copyright (C) 2015, Ahvaz Jundishapur University of Medical Sciences. This is an open-access article distributed under the terms of the Creative Commons Attribution-Non Commercial 4.0 International License (http://creativecommons.org/licenses/by-nc/4.0/) which permits copy and redistribute the material just in noncommercial usages, provided the original work is properly cited. 
sically, these processes are not efficient in removing dyes because of their high water solubility (2). The biological processes are not also effective in the removal of dyes from textile wastewater $(15,16)$. In recent years, the advanced oxidation process (AOP) has received more attention for the removal of recalcitrant pollutants in water and wastewater $(17,18)$. These processes are based on the production of hydroxyl radicals $\left(\mathrm{OH}^{\circ}\right)$ with high redox potential (1923). One of the common problems of all advanced oxidation processes are the electrical energy of the chemical reagent. In particular, an important energy input is required for producing photons with artificial light sources (4).

In this study, the photo-fenton process was conducted using $\mathrm{H}_{2} \mathrm{O}_{2}, \mathrm{Fe}^{+2}$, and $\mathrm{UV}$ radiation (580 nm) (24). In this process, $\mathrm{OH}^{\circ}$ was produced in the presence of ferrous $\left(\mathrm{Fe}^{+2}\right)$ and peroxide hydrogen as reductive and oxidative reagents, respectively. An increase in the degradation rate of the pollutant can be attributed to the oxidation of $\mathrm{Fe}$ (III) to $\mathrm{Fe}$ (II) by UV radiation, producing $\mathrm{OH}^{\circ}$ according to the following mechanism (Equation 1) (19):

$$
[\mathrm{FeOH}]^{2+}+\mathrm{UV} \rightarrow \mathrm{Fe}(\mathrm{II})+\mathrm{OH}^{0}
$$

Generally speaking, the AOP is an efficient environmentfriendly method in which $\mathrm{OH}^{\circ}$ is used to oxidize recalcitrant organic pollutants and convert them to harmless end-products such as $\mathrm{CO}_{2}$ and water (25).

The Fenton and photo-fenton processes have significant importance because of their high speed in removing contaminant materials and can be employed for the treatment of wastewater, especially textile and dyeing wastewater. Several studies have applied the photofenton process for the removal of organic matters from aqueous solutions. Mahmoodi et al. (21) showed that $89 \%$ of the acidic azo dye in their study was removed using the photo-fenton process. Another study indicated that the photo-fenton process removed 99\% of humic acid from aquatic solutions (24). Kang et al. (3) demonstrated that more than $96 \%$ of the dye in their study was removed from textile wastewater by the photo-fenton process. Elsewhere, Ebrahiem et al. (26) reported that 95\% of the organic contaminants in their investigation were removed from industrial wastewater with the process. Furthermore, Ay et al. (27) showed that the photo-Fenton process removed $100 \%$ of red azo dye. However, no studies until today have been conducted on removing Reactive Red 198 dye from aqueous solutions using the photoFenton process. The fenton and photo-fenton processes have significant importance because of their high speed in removing contaminant materials and can be used for the treatment of wastewater, especially textile and dyeing wastewater (28).

\section{Objectives}

The aims of the present study were to (i) evaluate the feasibility of using the photo-fenton process in remov- ing Reactive Red 198 dye from the aqueous phase and (ii) determine the Reactive Red 198 dye removal efficiency at optimal conditions.

\section{Materials and Methods}

This experimental study was done on a laboratory scale. The experiments were performed in triplicates. All data are presented based on the mean value. The studied parameters were reaction time ( 15 - 120 minutes), $\mathrm{H}_{2} \mathrm{O}_{2}$ concentration at 5 levels (50 - $150 \mathrm{mg} / \mathrm{L}$ ), Fe (II) concentration at 4 levels (10 - $200 \mathrm{mg} / \mathrm{L})$, and initial dye concentration at 4 levels (50 - $200 \mathrm{mg} / \mathrm{L})$, at different $\mathrm{pH}(3,5,7$, and 9). $\mathrm{NaOH}$ and $\mathrm{HCl}$ were used to adjust the $\mathrm{pH}$. The optimal conditions were determined according to maximum dye removal efficiency. Dye concentration was determined at a wavelength of $520 \mathrm{~nm}$ using a spectrophotometer (DR 5000) according to the standard method (No 2120) (29). The data were analyzed using the SPSS for Windows (version 16, SPSS Inc., Chicago, IL, USA) by Pearson's correlation coefficient to analyze the relationship between these parameters.

\subsection{Chemicals and Analytical Method}

Reactive Red 198 dye $\left(\mathrm{C}_{27} \mathrm{H}_{18} \mathrm{CIN}_{7} \mathrm{Na}_{4} \mathrm{O}_{15} \mathrm{~S}_{5}\right)$ was supplied by Hoechst Company, Germany. The rest of the chemicals were purchased from Merck (Germany). An 8-W UV lamp (F8T5), $25 \mathrm{~cm}$ in length, and $356 \mathrm{~nm}$ wave length (Hitachi, Japan), was used as the source of radiation for the photofenton processes.

\subsection{Reactor Specifications}

The experiment was performed in a 4-liter volume reactor (Figure 1). The source of radiation was a UV lamp protected by a quartz tube. The UV radiation source was immersed in the solution for better radiation. To prevent reflection, the reactor was wrapped in aluminum foil.

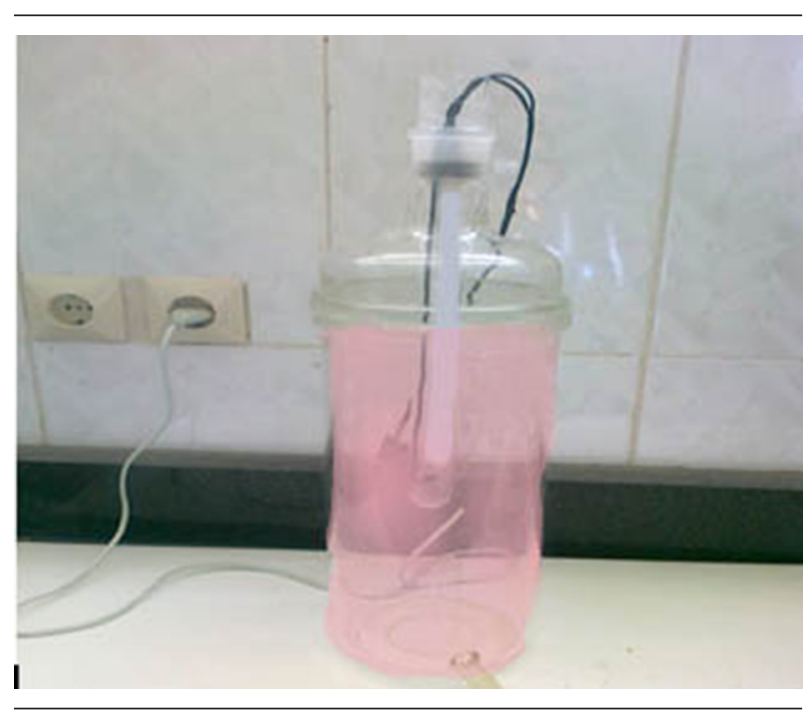

Figure 1. Specification of the Photochemical Reactor 
The dye removal efficiency was calculated by the following:(Equation 2)

$$
R(\%)=\frac{\left(\mathrm{A}_{0}-\mathrm{A}\right)}{A_{0}} \times 100
$$

Where AO and A represented the initial dye concentration before and after the photo-fenton process, respectively.

\section{Results}

\subsection{Effect of $p H$}

According to Figure 2, as pH increased from 3 to 5 , the dye removal rate decreased at a slower rate. Afterward, by increasing $\mathrm{pH}$ from 5 to 7 , the removal rate decreased with the higher rate. Based on our data obtained in the present study, a $\mathrm{pH}$ of 3 is optimal for dye degradation (36\%).

\subsection{Effect of Ferrous Iron (Fe (II)) Concentration}

Figure 3 shows the effect of Fe (II) on Reactive Red 198 dye removal efficiency at the defined parameters $\left(\mathrm{pH}=3, \mathrm{H}_{2} \mathrm{O}_{2}\right.$ concentration $=50 \mathrm{mg} / \mathrm{L}$, reaction time $=30$ minutes, and dye concentration $=50 \mathrm{mg} / \mathrm{L}$ ). The photo-fenton process was more efficient in the removal of Reactive Red 198 dye at Fe (II) concentration of 10 $\mathrm{mg} / \mathrm{L}$. Our data showed that as the Fe (II) concentration increased from 10 to $200 \mathrm{mg} / \mathrm{L}$, the removal efficiency of the reactive dye decreased from $81.98 \%$ to $43.42 \%$, respectively.

\subsection{Effect of $\mathrm{H} 2 \mathrm{O} 2$ Concentration}

Figure 4 shows the effect of $\mathrm{H}_{2} \mathrm{O}_{2}$ on Reactive Red 198 dye removal efficiency at the defined parameters $(\mathrm{pH}=3$, Fe (II) concentration $=10 \mathrm{mg} / \mathrm{L}$, reaction time $=30 \mathrm{~min}$ utes, and dye concentration $=50 \mathrm{mg} / \mathrm{L}$ ). In addition, $\mathrm{H}_{2} \mathrm{O}_{2}$ concentration of $75 \mathrm{mg} / \mathrm{L}$ was optimal and the removal efficiency was $84.53 \%$.

\subsection{Effect of Reactive Red 198 Dye's Initial Concen- tration}

The effect of the initial Reactive Red 198 dye concentration on its removal efficiency is presented in Figure 5. As the initial dye concentration increased from 50 to 200 $\mathrm{mg} / \mathrm{L}$, the removal efficiency was decreased. The maximum removal efficiency $(74.98 \%)$ was observed at the initial concentration of $50 \mathrm{mg} / \mathrm{L}$. However, an increase in the concentration of dye from 50 to $200 \mathrm{mg} / \mathrm{L}$ significantly decreased the removal rate $(36.76 \%$.). It can be concluded that the initial concentrations of Reactive Red 198 dye had a considerable effect on the removal of dye in the aqueous phase.

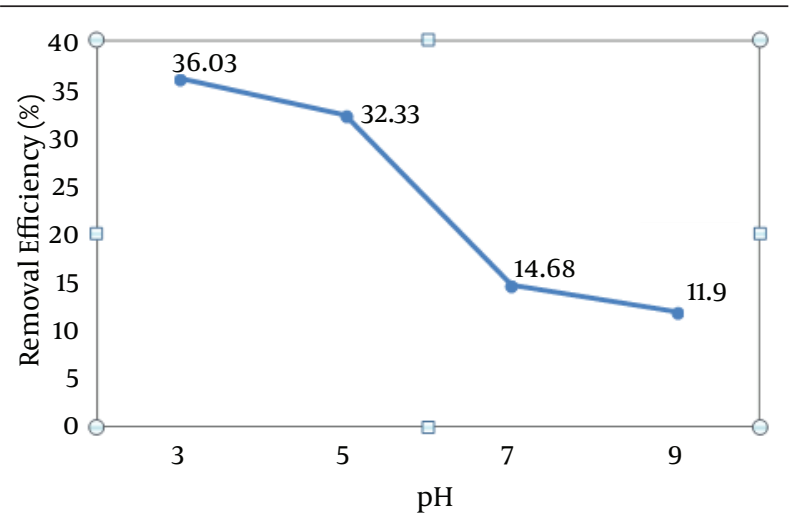

Figure 2. Effect of pH on the Reactive Red 198 (RR198) Dye Removal Efficiency by the Photo-Fenton Processes ( Fe (II) $=100 \mathrm{mg} / \mathrm{L}_{2} \mathrm{H}_{2} \mathrm{O}_{2}=50 \mathrm{mg} / \mathrm{L}$, Initial Dye Concentration $=50 \mathrm{mg} / \mathrm{L}$, Contact Time $=30$ minutes $)$

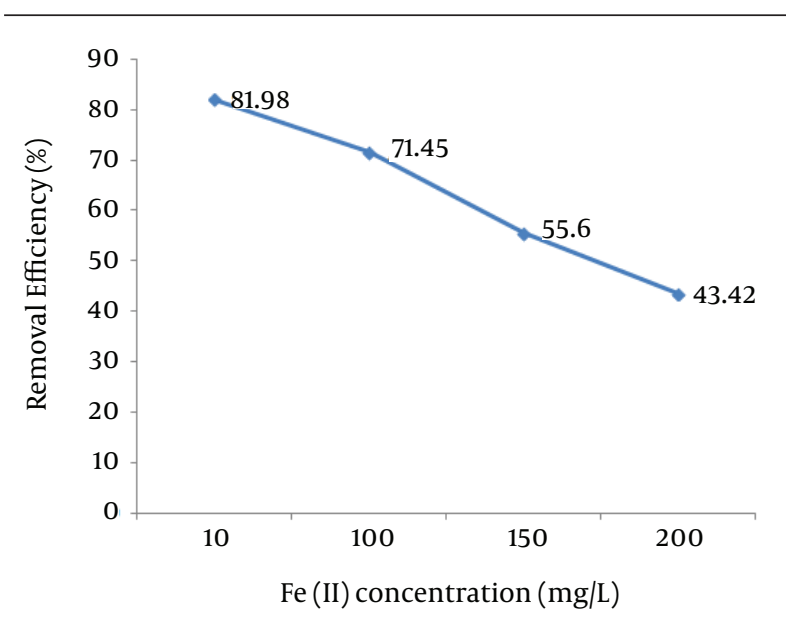

Figure 3. Effect of Ferrous Ion (Fe (II)) Concentrations on the Reactive Red 198 (RR198) Dye Removal Efficiency by the Photo-Fenton Processes ( $\mathrm{pH}=3$ $\mathrm{H}_{2} \mathrm{O}_{2}$ Concentration $=50 \mathrm{mg} / \mathrm{L}$, Initial Dye Concentration $=50 \mathrm{mg} / \mathrm{L}$, Contact Time $=30$ minutes)

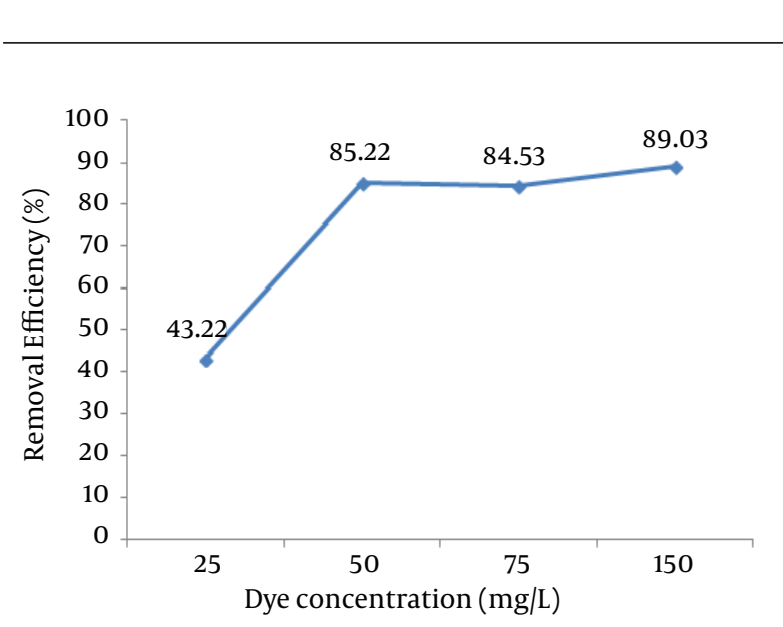

Figure 4. Effect of $\mathrm{H}_{2} \mathrm{O}_{2}$ Concentrations on the Reactive Red 198 (RR198) Dye Removal Efficiency by the Photo-Fenton Processes $(\mathrm{pH}=3$, Fe (II) $=10$ $\mathrm{mg} / \mathrm{L}$, Initial Dye Concentration $=50 \mathrm{mg} / \mathrm{L}$, Contact Time $=30$ minutes $)$ 


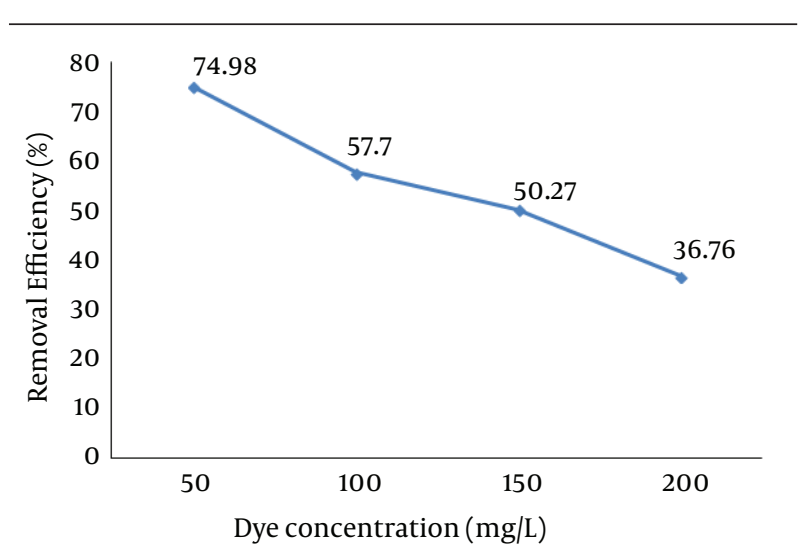

Figure 5. Effect of the Initial Dye Concentration on the Reactive Red 198 (RR198) Dye Removal Efficiency by the Photo-Fenton Processes ( $\mathrm{pH}=3$, Fe (II) $=10 \mathrm{mg} / \mathrm{L}, \mathrm{H}_{2} \mathrm{O}_{2}=75 \mathrm{mg} / \mathrm{L}$, Contact time $=30$ minutes $)$

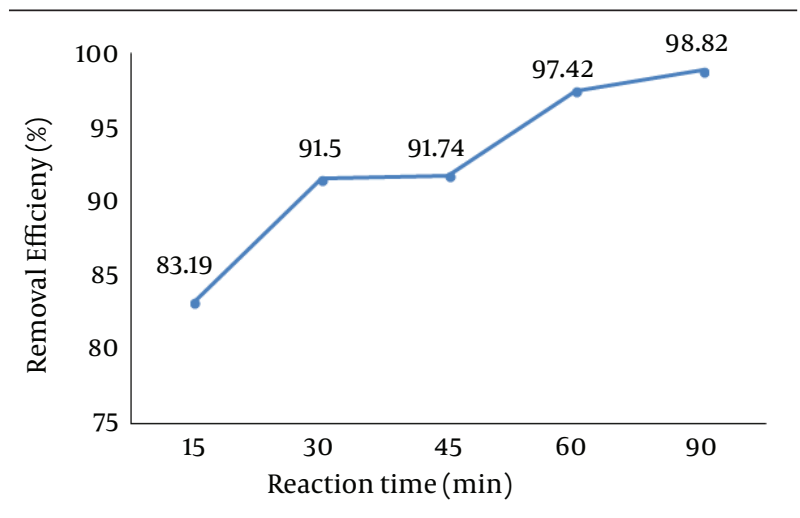

Figure 6. Effect of Reaction Time on the Reactive Red 198 (RR198) Dye Removal Efficiency by the Photo-Fenton Processes ( $\mathrm{pH}=3, \mathrm{Fe}(\mathrm{II})=10 \mathrm{mg} / \mathrm{L}$, $\mathrm{H}_{2} \mathrm{O}_{2}=75 \mathrm{mg} / \mathrm{L}$, Initial Dye Concentration $=50 \mathrm{mg} / \mathrm{L}$ )

\subsection{Effect of Reaction Time}

The effect of reaction time on the Reactive Red 198 (RR198) dye removal efficiency is depicted in Figure 6. Based on this figure, increasing the reaction time resulted in an increase in the removal efficiency. The removal efficiency increased from $83.19 \%$ at 15 minutes reaction time to $98.8 \%$ after 120 minutes.

\section{Discussion}

Many studies have demonstrated that $\mathrm{pH}$ plays an important role in the advanced oxidation processes (30). Moreover, the $\mathrm{OH}^{\circ}$ is produced under acidic condition and it is also more stable in this condition $(31,32)$. According to Equation 3, Fe (II) is oxidized to Fe (III) and the $\mathrm{OH}^{\circ}$ with very high redox potential is produced (Equation 3$)(3,33)$.

$$
\mathrm{Fe}(\mathrm{II})+\mathrm{H}_{2} \mathrm{O}_{2} \rightarrow \mathrm{Fe}^{3+}+\mathrm{OH}^{-}+\mathrm{OH}^{0}
$$

At a pH lower than 3, the generated ferric hydroxide reacted with $\mathrm{H}_{2} \mathrm{O}_{2}$, which resulted in a decrease in the $\mathrm{OH}^{\circ}$, eventually decreasing the removal efficiency (34).

According to Figure 2, the maximum removal efficiency was related to a $\mathrm{pH}$ of 3 , which has also been concluded by other researches $(24,26)$. Ebrahiem et al. (26) showed that a $\mathrm{pH}$ of 3 was optimum for the removal of organic contaminants from industrial wastewater using the photo-Fenton process. Another study showed that the maximum removal of humic acid from organic solutions occurred at a pH of 4 using the photo-fenton process (99\%) (24). For the degradation of azo dyes using both fenton and fenton-like reactions, the optimum $\mathrm{pH}$ is about 2.5 0.3 (35). According to the results illustrated in Figure 2, first the removal rate of the dye decreased significantly as the $\mathrm{pH}$ increased from 3 to 5 . Afterward, the decreased removal rate became sharper ( $\mathrm{pH}$ from 5 to 7 ).

Perez et al. (4) demonstrated that organic chlorine was removed from paper bleaching units during alkaline hydrolysis. Overall, previous findings have indicated that both Fenton and photo-fenton processes are successful in removing carmoisine dye from aqueous solutions (25). According to a study by Xu et al. (36), since a combination of UV and fenton processes produces the $\mathrm{OH}^{\circ}$ directly, the decolorization of dyes can be accelerated.

Figure 3 demonstrates that the maximum dye removal efficiency was observed at Fe (II) concentration of 10 $\mathrm{mg} / \mathrm{L}$. However, the addition of extra Fe (II) concentrations more than $10 \mathrm{mg} / \mathrm{L}$ resulted in a reduction in the process efficiency and acted as a scavenger for the $\mathrm{OH}^{\circ}$ (29). Biglari et al. (24) also concluded that by increasing Fe (II) concentrations more than the optimum level, the removal efficiency of humic acid dramatically decreased. According to Figure 4, the maximum dye removal efficiency was found at $\mathrm{H}_{2} \mathrm{O}_{2}$ concentrations of $75 \mathrm{mg} / \mathrm{L}$. Increasing $\mathrm{H}_{2} \mathrm{O}_{2}$ to more than the optimal concentration may enhance the production of $\mathrm{OOH}^{-}$, which consumes the $\mathrm{OH}^{\circ}$ and decreases the removal rate (24). Rahmani et al. (37) revealed that BV16 and RR120 removal rates were accelerated by increasing the concentration of $\mathrm{H}_{2} \mathrm{O}_{2}$ until to the optimum level, after which point the dye removal efficiency decreased.

According to Figure 5, increasing the initial dye concentration to more than $50 \mathrm{mg} / \mathrm{L}$ resulted in a decrease in the removal efficiency. Indeed, increasing the dye concentration decreased the penetration of the UV light and reduced the production of the $\mathrm{OH}^{\circ}$, eventually leading to a reduction in the removal efficiency. The same results were obtained from another study which reported that the maximum removal of Acid Orange 7 and Reactive Black 5 was at the initial concentration of $50 \mathrm{mg} / \mathrm{L}$. According to the results, as the initial dye concentration exceeded $50 \mathrm{mg} / \mathrm{L}$, the dye removal efficiency decreased.

Based on the data illustrated in Figure 6, an increase in the reaction time was in tandem with a rise in the removal efficiency. Accordingly, the removal efficiencies at 15 and 120 minutes were $88.19 \%$ and $98.8 \%$, respectively. The photo-fenton oxidation process can be used as a suitable method for the removal of highly contaminated 
waters that contain large amounts of 3-Aminopyridine compound, and the removal rate can be augmented by increasing the reaction time (38). The fact that dye removal rates can be enhanced by increasing the reaction time (39) can be attributed to the high production of the $\mathrm{OH}^{\circ}$. Another study showed that the Fenton process was able to decolorize textile wastewater at 20 - 40 minutes reaction time. Other studies have shown that high dye removal efficiency was achieved at 120 minutes (40). Zheng et al. (41) indicated that at 120 minutes, the dye removal rates were $21.3 \%$ and $95.3 \%$ in the fenton and photo-fenton processes, respectively, which revealed the higher efficiency of the photo-fenton process in comparison to the fenton process. The authors also stated that the production of more $\mathrm{OH}^{\circ}$ results in the higher efficiency of the photo-Fenton process compared to the fenton process.

The present study also demonstrated that more than 99.12\% of the Reactive Red 198 dye was removed at 120 minutes.

In conclusion, the obtained results suggest that the photo-Fenton process significantly removed Reactive Red 198 dye in the liquid phase. The removal of the dye was decreased with increasing $\mathrm{pH}$ and increased with the reaction time. The optimal conditions for the removal of dye from the aqueous phase using the photo-fenton process $\left(\mathrm{UV} / \mathrm{H}_{2} \mathrm{O}_{2} / \mathrm{Fe}(\mathrm{II})\right)$ was determined at a $\mathrm{pH}$ of 3, Fe (II) concentration of $10 \mathrm{mg} / \mathrm{L}, \mathrm{H}_{2} \mathrm{O}_{2}$ concentration of $75 \mathrm{mg} / \mathrm{L}$, and dye concentration of $50 \mathrm{mg} / \mathrm{L}$. Moreover, the dye removal efficiency from aqueous solutions was more than $99 \%$ at optimal conditions. Therefore, the study results indicated that the $\mathrm{UV} / \mathrm{H}_{2} \mathrm{O}_{2} / \mathrm{Fe}$ (II) process could be used as an effective method to remove Reactive Red 198 dye from industrial wastewater. Due to the financial limitations of the project, we only determined the removal efficiency of Reactive Red 198 dye using a spectrophotometer (DR 5000). Therefore, it is highly recommended that future studies use the gas chromatography-mass spectrometry (GC-MS) method to determine the intermediate compound which may be produced from the photo-fenton reaction.

\section{Acknowledgements}

The authors would like to thank the Deputy of Research and Technology of Shiraz University of Medical Sciences for its financial support for the research project of 937366. We wish to acknowledge Ms. A. Keivanshekouh at the Research Improvement Center of Shiraz University of Medical Sciences for improving the use of English in the manuscript.

\section{Authors' Contributions}

The overall implementation of this study, including design, experiments, and data analysis, and manuscript preparation were the results of the corresponding author's efforts. All authors have made extensive contributions to the review and finalization of this manuscript. All authors read and approved the final manuscript.

\section{References}

1. Alizadeh M, Bazrafshan E, Mahvi A, Kord Mostafapour F, Ghahremani A. Efficiency of pistacia atlantica extract as natural coagulant in removal of Reactive Red 198 dye from aqueous solution. Kordestan Univ Med Sci. 2014;19(1):124-34.

2. Zazouli MA, Balarak D, Mahdavi Y, Ebrahimi M. Adsorption rate of 198 reactive red dye from aqueous solutions by using activated red mud. Iran J Health Sci. 2013;1(1):36-43.

3. Kang SF, Liao $\mathrm{CH}$, Chen MC. Pre-oxidation and coagulation of textile wastewater by the Fenton process. Chemosphere. 2002;46(6):923-8.

4. Perez M, Torrades F, Domenech X, Peral J. Fenton and photo-Fenton oxidation of textile effluents. Water Res. 2002;36(11):2703-10.

5. Lin SH, Peng CF. Treatment of textile wastewater by electrochemical method. Water Res. 1994;28(2):277-82.

6. dos Santos AB, Cervantes FJ, van Lier JB. Review paper on current technologies for decolourisation of textile wastewaters: perspectives for anaerobic biotechnology. Bioresour Technol. 2007;98(12):2369-85.

7. Lee JW, Choi SP, Thiruvenkatachari R, Shim WG, Moon H. Evaluation of the performance of adsorption and coagulation processes for the maximum removal of reactive dyes. Dyes Pigm. 2006;69(3):196-203.

8. Junnarkar N, Murty DS, Bhatt NS, Madamwar D. Decolorization of diazo dye Direct Red 81 by a novel bacterial consortium. World J Microbiol Biotechnol. 2006;22(2):163-8.

9. Crini G. Studies on adsorption of dyes on beta-cyclodextrin polymer. Bioresour Technol. 2003;90(2):193-8.

10. Arami M, Limaee NY, Mahmoodi NM, Tabrizi NS. Equilibrium and kinetics studies for the adsorption of direct and acid dyes from aqueous solution by soy meal hull. J Hazard Mater. 2006;135(1-3):171-9.

11. Mahmoodi NM, Masrouri O, Najafi F. Dye removal using polymeric adsorbent from wastewater containing mixture of two dyes. Fiber Polymers. 2014;15(8):1656-68.

12. Mohan SV, Rao NC, Srinivas S, Prasad KK, Karthikeyan J. Treatment of simulated Reactive Yellow 22 (azo) dye effluents using Spirogyra species. Waste Manag. 2002;22(6):575-82.

13. Ghaneian MT, Ehrampoush MH, Ghanizadeh GH, Dehvary M Abootoraby M, Jasemizad T. Application of Solar Irradiation/ K2S2O8 Photochemical Oxidation Process for the Removal of Reactive Blue 19 Dye fromAqueous Solutions. Iran J Health Environ. 2010;3(2):165-76.

14. Dehghani M, Shamsedini N. Application of Electrocoagulation Process for Reactive Red 198 Dye Removal from the Aqueous Solution. Iran J Health Sci. 2014;2(2):1-9.

15. Saadatjou N, Rasoulifard MH, Heidari A. Removal of Basic Red 46 using low-cost adsorbent of hardened paste of portland cement from contaminated water.J Color Sci Tech. 2009;2(4):221-6.

16. Yazdanbakhsh AR, Sheikh Mohammadi A, Sardar M, Mohammadi H, Zarabi M. Investigation of Iron Powder, Hydrogen Peroxide and Iron Hydrogen Peroxide for Removal of Acid Yellow Powder 36 Dye from Aqueous Solutions. Iran J Health Environ. 2010;2(4):296-303.

17. Zuorro A, Lavecchia R. Evaluation of UV/H2O2 advanced oxidation process (AOP) for the degradation of diazo dye Reactive Green 19 in aqueous solution. Desalination Water Treatm . 2014;52(7-9):1571-7.

18. Aleboyeh A, Olya ME, Aleboyeh H. Electrical energy determination for an azo dye decolorization and mineralization by UV] H2O2 advanced oxidation process. Chem EngJ. 2008;137.

19. Vaishnave P, Kumar A, Ameta R, Punjabi PB, Ameta SC. Photo oxidative degradation of azure-B by sono-photo-Fenton and photoFenton reagents. Arab J Chem. 2014;7(6):981-5.

20. Chanderia K, Kumar S, Sharma J, Ameta R, Punjabi PB. Degradation of Sunset Yellow FCF using copper loaded bentonite and $\mathrm{H} 2$ O 2 as photo-Fenton like reagent. Arab J Chem. 2012;Inpress.

21. Mahmoodi N, Rayat-Tari K, Borhany S, Arami M, Nourmohammadian F. Decolorization of colored wastewater containing azo acid dye using photo-fenton process: Operational parameters and a comparative study.J Color Sci Tech. 2008;2(1):31-40.

22. Dehghani M, Shahsavani E, Farzadkia M, Samaei MR. Optimizing 


\section{Dehghani M et al.}

photo-Fenton like process for the removal of diesel fuel from the aqueous phase.J Environ Health Sci Eng. 2014;12:87.

23. Farzadkia M, Dehghani M, Moafian M. The effects of Fenton process on the removal of petroleum hydrocarbons from oily sludge in Shiraz oil refinery, Iran. J Environ Health Sci Eng. 2014;12(1):31.

24. Biglari H, Kord Mostafapour F, Joneidi Jafari A, Bazrafshan E. Removal of Humic acid from environmental aqueous by Fenton Oxidation Process. Khorasan Univ Med Sci. 2013;5(1):37-45.

25. Sohrabi MR, Khavaran A, Shariati S, Shariati S. Removal of Carmoisine edible dye by Fenton and photo Fenton processes using Taguchi orthogonal array design. Arab J Chem. 2014.

26. Ebrahiem EE, Al-Maghrabi MN, Mobarki AR. Removal of organic pollutants from industrial wastewater by applying photo-Fenton oxidation technology. Arab JChem. 2013;Inpress.

27. Ay F, Catalkaya EC, Kargi F. A statistical experiment design approach for advanced oxidation of Direct Red azo-dye by photoFenton treatment. J Hazard Mater. 2009;162(1):230-6.

28. Khataee A, Daneshvar N, Rasoulifard MH, Doraji MS. Removal of organic dyes from industrial wastewaters using $\mathrm{UV} / \mathrm{H} 2 \mathrm{O} 2$, $\mathrm{UV} / \mathrm{H} 2 \mathrm{O} 2 / \mathrm{Fe}$ (II), UV/H2O2/Fe (III) processes. Water Wastewater 2007;61:34-42.

29. American Public Health Association.. Standards Methods for the Examination of Water and Wastewaters. 20th edWashington, DC: American Public Health Association; 2005.

30. Orooji N, Takdastan A, Kargari A, Raeesi G. Efficiency of Chitosan with Polyaluminum Chloride in Turbidity Removal from Ahwaz Water Treatment Plant Influent. Water Wastewater. 2011;4:70-7.

31. Peternel I, Koprivanac N, Kusic H. UV-based processes for reactive azo dye mineralization. Water Res. 2006;40(3):525-32.
32. Fang J, Shan XQ, Wen B, Lin JM, Owens G. Stability of titania nanoparticles in soil suspensions and transport in saturated homogeneous soil columns. Environ Pollut. 2009;157(4):1101-9.

33. Kavitha V, Palanivelu K. The role of ferrous ion in Fenton and photo-Fenton processes for the degradation of phenol. Chemosphere. 2004;55(9):1235-43.

34. Bahmani P, Maleki A, Ghahremani A, Kohzadi S. Efficiency of Fenton Oxidation Process in Removal of Remazol Black-B from Aqueous Medium. J Health Hyg . 2014;4(1):57-67.

35. Hsueh CL, Huang YH, Wang CC, Chen CY. Degradation of azo dyes using low iron concentration of Fenton and Fenton-like system. Chemosphere. 2005;58(10):1409-14.

36. Xu Y. Comparative studies of the Fe3+|2+-UV, H2O2-UV, TiO2-UV| vis systems for the decolorization of a textile dye $\mathrm{X}-3 \mathrm{~B}$ in water. Chemosphere. 2001;43(8):1103-7.

37. Rahmani Z, Kermani M, Gholami M, Jafari AJ, Mahmoodi NM. Effectiveness of photochemical and sonochemical processes in degradation of Basic Violet 16 (BV16) dye from aqueous solutions. Iranian J Environ Health Sci Eng. 2012;9(1):14.

38. Karale RS, Manu B, Shrihari S. Fenton and Photo-fenton Oxidation Processes for Degradation of 3-Aminopyridine from Water. APCBEE Procedia. 2014;9:25-9.

39. Takdastan A, Emami Tabar S, Neisi A, Eslami A. Fluoride Removal From Drinking Water by Electrocoagulation Using Iron and Aluminum Electrodes. Jundishapur J Health Sci. 2014;6(3).

40. Arami M, Yousefi Limaee N, Mahmoodi NM. Investigation on the adsorption capability of egg shell membrane towards model textile dyes. Chemosphere. 2006;65(11):1999-2008.

41. Zheng H, Pan Y, Xiang X. Oxidation of acidic dye Eosin Y by the solar photo-Fenton processes. J Hazard Mater. 2007;141(3):457-64. 